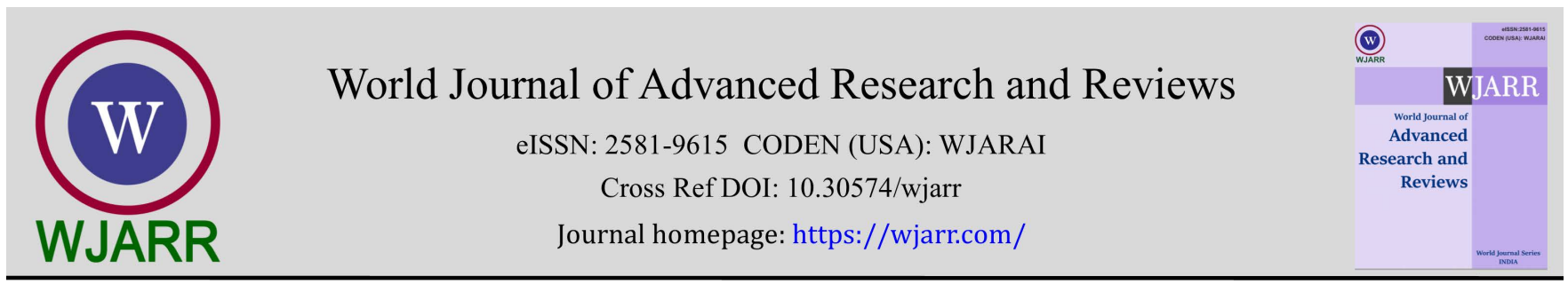

(REVIEW ARTICLE)

\title{
The impact of digital screen use on myopia progression in COVID-19 pandemic: A systematic review
}

\author{
Sinta Dwi Juniar ${ }^{1}$, Innas Safira Putri ${ }^{1}$, Tasya Wikassa ${ }^{1}$ and Reny I'tishom 2,* \\ ${ }^{1}$ Medical Program, Faculty of Medicine, Universitas Airlangga, Surabaya, Indonesia. \\ 2 Department of Biomedical Science, Faculty of Medicine, Universitas Airlangga, Surabaya, Indonesia.
}

World Journal of Advanced Research and Reviews, 2022, 13(01), 210-222

Publication history: Received on 04 December 2021; revised on 05 January 2022; accepted on 07 January 2022

Article DOI: https://doi.org/10.30574/wjarr.2022.13.1.0009

\begin{abstract}
The new coronavirus disease of 2019 (COVID-19) had a worldwide impact, this disease was affecting almost everyone's lives. It has caused many health issues to spiral out of control, one of them is myopia. Evidence suggests that myopia is impacted by environmental and lifestyle factors, with the importance of continuous usage of nearby digital screens being highlighted. The systematic review aims to analyze all the available information about the impact of digital screen use on myopia progression in a COVID-19 pandemic. The literature was searched from e-database PubMed and ScienceDirect. Quality assessment was done using the LEGEND (Let Evidence Guide Every New Decision) Evidence Evaluation Tools \& Resources. A total of 10 papers were assessed qualitatively. The prevalence or incidence of myopia was reported in all ten studies. All of the studies discussed in this review suggest a relationship or impact between digital screen use and myopia progression. Four (40\%) of the ten studies were cross-sectional, while the other six (60\%) were cohort studies. The sample size ranged from 115 to 123535 participants. The majority of the participants in the studies were school-age children (primary and secondary school), but one study included university students. There were three studies involving subjects with myopia at baseline, one study involving subjects without myopia at baseline, and six studies involving subjects with myopia and without myopia. This systematic review shows that there is a significant progression of myopia as an impact of digital screen use during the COVID-19 pandemic.
\end{abstract}

Keywords: Digital screen; Myopia; COVID-19; Health risk; Healthy lifestyle

\section{Introduction}

The new coronavirus disease of 2019 (COVID-19) had a worldwide impact, this disease was affecting almost everyone's lives [1]. The worldwide pandemic COVID-19, which was declared by the World Health Organization on March 11, 2020 has caused many health issues to spiral out of control, one of them is myopia [2]. Myopia as one of the most common ocular illnesses in the world has developed dramatically in the previous 20-30 years, accounting for about 2620 million cases in $2020[3,4]$. As one of the leading contributors of irreversible blindness, myopia is expected to affect half of the world's population by 2050 [4].

Given the state of the COVID-19 pandemic, "lockdown" has finally evolved in a lot of governments, with the goal of decreasing COVID-19 transmissions by limiting human contact. People are forced to stay indoors as a result of the "lockdown." Because of the pandemic, practically all activities that are usually conducted are now restricted. Regulations such as home confinement, school closures, and working from home need eventually be implemented [5]. Due to school closures and home confinement as an impact of the COVID-19 pandemic, schools have begun to use digital teaching methods, as well as all classes must now be held online. As a result, on average, a child spends approximately 4 to 6 hours each day on these gadgets for academic purposes or for playing as well [5]. Not only in children, but a new study

\footnotetext{
* Corresponding author: Reny I'tishom

Departement of Biomedical Science, Faculty of Medicine, Universitas Airlangga, Surabaya, Indonesia.

Copyright $(2022$ Author(s) retain the copyright of this article. This article is published under the terms of the Creative Commons Attribution Liscense 4.0.
} 
reveals that prolonged exposure to electronic gadgets and digital screens during the COVID-19 pandemic may have a negative influence on adolescent visual development [6].

According to studies, overall near-work and screen time was more than double what it was pre-COVID-19 during the pandemic [7]. Increased digital screen time has been known to have correlated with the onset and progression of myopia, and this case might likely worsen during and after the COVID-19 pandemic phase [6, 8]. Due to these conditions, the possible vision health risks as a result of learning under the current COVID-19 pandemic would almost probably increase the already serious global youth vision crisis, including cases of myopia [9].

Evidence suggests that myopia is impacted by environmental and lifestyle factors, with the importance of continuous usage of nearby digital screens being highlighted $[10,11,12]$. Although home confinement against the pandemic will not last continuously, the growing usage and dependence on digital gadgets, as well as behavioral changes caused by prolonged home confinement, may have long-term consequences on myopia progression in the population [6]. In response, we did a systematic review to collect all the available information about the impact of digital screen use on myopia progression in a COVID-19 pandemic. Hopefully, this review can help readers understand the impact of digital screen use on myopia progression during the pandemic, so that follow-up actions can be created to deal with newly emerged health cases, as the global goals, each of which is listed in the Sustainable Development Goals (SDGs) as good health and well-being, can also be achieved together.

\section{Material and methods}

\subsection{Study design}

This study is based on the PRISMA principles and is a systematic review.

\subsection{Search strategies}

A literature search in this study was conducted through the PubMed and Science Direct electronic databases to systematically identify relevant research. The literature search was carried out using Boolean Operators with search terms including (Myopia) AND (COVID-19). The keywords used are entered together into the electronic database search engine using the advanced search.

\subsection{Inclusion and exclusion criteria}

Included studies met the following inclusion criteria:

- $\quad$ Research published in the last three years (2020-2022)

- $\quad$ Research conducted during the COVID-19 pandemic

- $\quad$ Literature in English

- Full-text literature accessible

- The subjects of the study have been exposed to digital screen during COVID-19

- $\quad$ The study included the progression of myopia

The following studies were not included in the study:

- $\quad$ The research was conducted before the COVID-19 pandemic

- $\quad$ Sources come from non-research studies (conference papers, book chapters, reports)

- The subject of the studies are exposed to other than digital screen

- $\quad$ Literature review (literature review, systematic review)

\subsection{Data extraction}

Before retrieving the entire text, the three reviewers separately evaluated and analyzed the title and abstracts. The data extracted from these studies included the author, year of publication, title, country, number of participants, participants age/ grade, study type, screen exposure, refractive measurement, and the results. Excel 2010 software program was used to organize extracted study data. 


\subsection{Quality assessment}

The LEGEND (Let Evidence Guide Every New Decision) Evidence Evaluation Tools \& Resources was used by the three reviewers to grade the study's quality. For articles with the cohort method, this tool consists of 17 questions. For a crosssectional study, this tool consists of 14 questions. There are three kinds of answer choices: Yes (Y), No (N), and Unknown $(\mathrm{U})$. The final result is obtained from the conclusion of the whole answer whether the journal can be Good Quality or Lesser Quality.

\subsection{Data synthesis}

The results found will be analyzed in a narrative format, with descriptions and explanations to aid comprehension and provide more obvious conclusions to the reader.

\section{Results}

\subsection{Study selection}

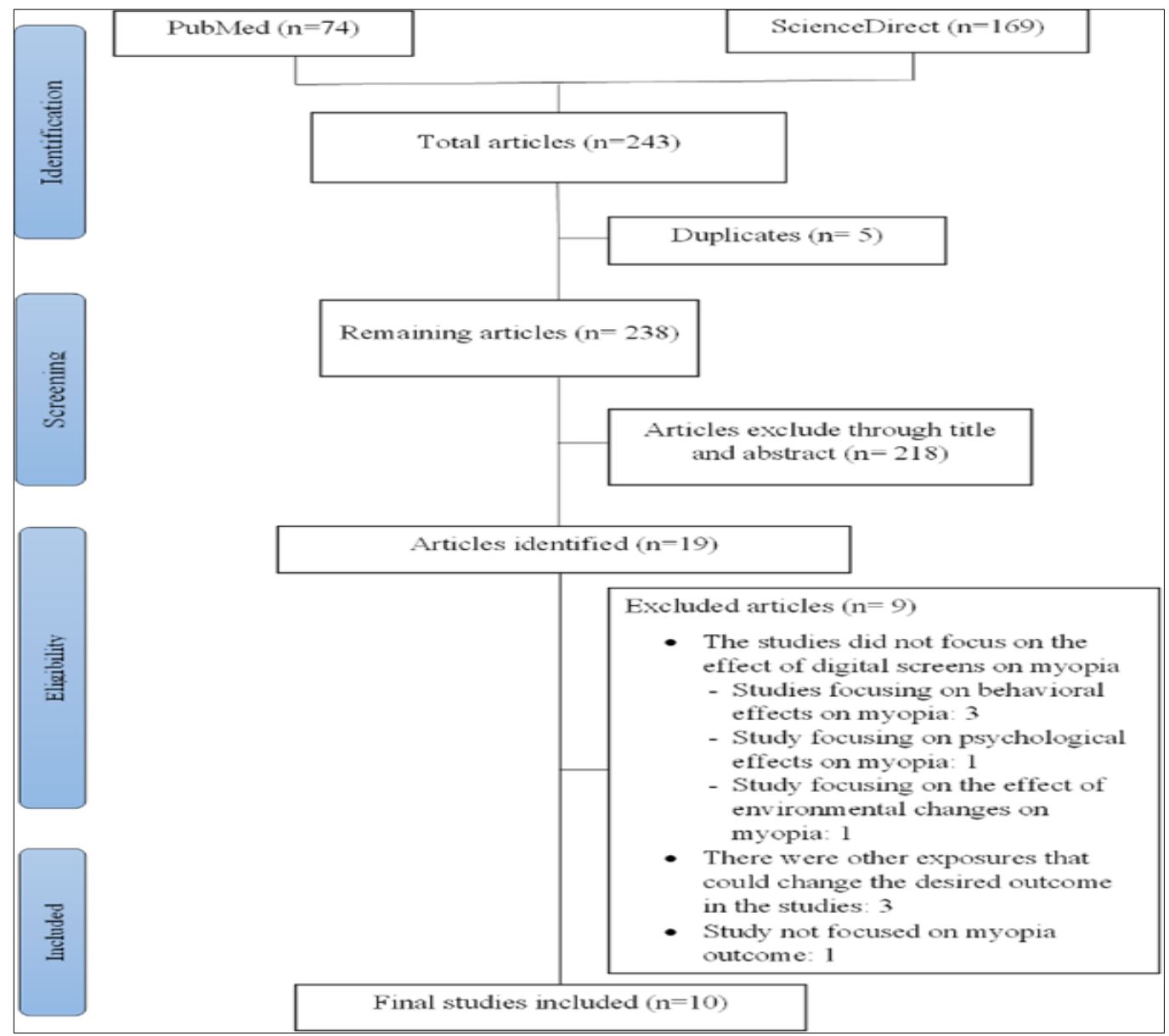

Figure 1 Framework of the systematic review

The initial search yielded 243 scientific papers from the databases PUBMED and ScienceDirect (Figure. 1). The duplicates were removed, leaving 238 papers for screening in title and abstract. After the screening, we excluded 218 that did not match with the theme, leaving a total of 19 papers to be analyzed in full text. This analysis resulted in the exclusion of 9 papers. The four articles did not focus on the effect of digital screens on myopia, it covers 3 studies focusing on behavioral effects on myopia, 1 study focusing on psychological effects on myopia, and 1 study focusing on the effect of environmental changes on myopia. Other studies that are not suitable are also due to in 3 studies there were other exposures that could change the desired outcome, and 1 study not focused on myopia outcome. After removing all the excluded studies, a total of 10 papers were assessed qualitatively. 


\subsection{Quality assessment}

The LEGEND (Let Evidence Guide Every New Decision) Evidence Evaluation Tools \& Resources is used to assess the quality of evidence for all research that meets the requirements. Table 1 and 2 shows the details of the assessment results for each component, as well as the ten studies that meet the assessment points.

Table 1 Study quality assessment criteria using the Cohort LEGEND's tool

\begin{tabular}{|c|c|c|c|c|c|c|c|c|c|c|c|c|c|c|c|c|c|c|}
\hline \multirow{2}{*}{ Author (year) } & \multirow{2}{*}{$\begin{array}{l}\text { Assist in answering } \\
\text { the clinical question }\end{array}$} & \multirow{2}{*}{$\begin{array}{l}\text { Cohort study } \\
\text { congruent }\end{array}$} & \multicolumn{7}{|c|}{ Validity } & \multicolumn{5}{|c|}{ Reliability } & \multicolumn{3}{|c|}{ Applicability } & \multirow{2}{*}{ Overall results } \\
\hline & & & 1 & 2 & 3 & 4 & 5 & 6 & 7 & 8 & 9 & 10 & 11 & 12 & 13 & 14 & 15 & \\
\hline Aslan et al., 2021 & $\mathrm{Y}$ & Y & $\mathrm{Y}$ & $\mathrm{Y}$ & $\mathrm{Y}$ & $\mathrm{Y}$ & $\mathrm{Y}$ & $\mathrm{Y}$ & $\mathrm{Y}$ & $\mathrm{N}$ & $\mathrm{Y}$ & $\mathrm{Y}$ & $\mathrm{N}$ & $\mathrm{Y}$ & $\mathrm{Y}$ & $\mathrm{Y}$ & $\mathrm{Y}$ & Good Quality \\
\hline Liu et al., 2021 & $\mathrm{Y}$ & Y & $\mathrm{Y}$ & $\mathrm{Y}$ & $\mathrm{N}$ & $\mathrm{Y}$ & $\mathrm{Y}$ & $\mathrm{Y}$ & $\mathrm{Y}$ & $\mathrm{Y}$ & $\mathrm{Y}$ & $\mathrm{Y}$ & $\mathrm{Y}$ & Y & $\mathrm{Y}$ & $\mathrm{Y}$ & $Y$ & Good Quality \\
\hline${ }^{1}$ Ma et al., 2021 & $\mathrm{Y}$ & Y & $\mathrm{Y}$ & $\mathrm{Y}$ & $\mathrm{Y}$ & $\mathrm{Y}$ & $\mathrm{Y}$ & $\mathrm{Y}$ & $\mathrm{Y}$ & $\mathrm{N}$ & Y & $\mathrm{Y}$ & $\mathrm{Y}$ & $\mathrm{Y}$ & $\mathrm{Y}$ & $\mathrm{Y}$ & $Y$ & Good Quality \\
\hline${ }^{2}$ Ma et al., 2021 & $\mathrm{Y}$ & Y & $\mathrm{Y}$ & $\mathrm{Y}$ & $\mathrm{Y}$ & $\mathrm{Y}$ & $\mathrm{Y}$ & $\mathrm{Y}$ & $\mathrm{N}$ & $\mathrm{N}$ & Y & Y & $Y$ & Y & $\mathrm{Y}$ & $Y$ & Y & Good Quality \\
\hline Zhang et al., 2021 & $\mathrm{Y}$ & Y & $Y$ & $\mathrm{Y}$ & $\mathrm{Y}$ & $\mathrm{Y}$ & $\mathrm{Y}$ & $\mathrm{Y}$ & $Y$ & $\mathrm{Y}$ & Y & Y & $\mathrm{N}$ & Y & $\mathrm{Y}$ & $Y$ & $\mathrm{Y}$ & Good Quality \\
\hline Mohan et al., 2022 & $\mathrm{Y}$ & $\mathrm{Y}$ & $\mathrm{Y}$ & Y & $\mathrm{Y}$ & $\mathrm{Y}$ & $\mathrm{Y}$ & $\mathrm{Y}$ & $\mathrm{Y}$ & $\mathrm{N}$ & $\mathrm{Y}$ & $\mathrm{Y}$ & $\mathrm{Y}$ & $\mathrm{Y}$ & $\mathrm{Y}$ & Y & $\mathrm{Y}$ & Good Quality \\
\hline
\end{tabular}

1. Ma M, Xiong S, Zhao S, Zheng Z, Sun T, Li C. COVID-19 Home Quarantine Accelerated the Progression of Myopia in Children Aged 7 to 12 Years in China; ${ }^{2}$ Ma D, Wei S, Li SM, Yang X, Cao K, Hu J, Fan S, Zhang L, Wang N. Progression of myopia in a natural cohort of Chinese children during COVID-19 pandemic

Table 2 Study quality assessment criteria using the Cross-sectional LEGEND's too

\begin{tabular}{|c|c|c|c|c|c|c|c|c|c|c|c|c|c|c|c|}
\hline \multirow{2}{*}{ Author (year) } & \multirow{2}{*}{$\begin{array}{l}\text { Assist in answering } \\
\text { the clinical } \\
\text { question }\end{array}$} & \multirow{2}{*}{$\begin{array}{l}\text { Cross-sectional } \\
\text { study congruent }\end{array}$} & \multicolumn{4}{|c|}{ Validity } & \multicolumn{5}{|c|}{ Reliability } & \multicolumn{3}{|c|}{ Applicability } & \multirow{2}{*}{$\begin{array}{l}\text { Overall } \\
\text { results }\end{array}$} \\
\hline & & & 1 & 2 & 3 & 4 & 5 & 6 & 7 & 8 & 9 & 10 & 11 & 12 & \\
\hline${ }^{1}$ Liu et al., 2021 & $\mathrm{Y}$ & $\mathrm{Y}$ & $\mathrm{Y}$ & $\mathrm{Y}$ & $\mathrm{N}$ & $\mathrm{Y}$ & $\mathrm{Y}$ & $\mathrm{Y}$ & $\mathrm{Y}$ & $\mathrm{Y}$ & $\mathrm{Y}$ & $\mathrm{Y}$ & $\mathrm{Y}$ & $\mathrm{Y}$ & Good Quality \\
\hline${ }^{2}$ Liu et al., 2021 & $\mathrm{Y}$ & $\mathrm{Y}$ & $\mathrm{Y}$ & $\mathrm{Y}$ & $\mathrm{N}$ & $\mathrm{Y}$ & $\mathrm{Y}$ & $\mathrm{Y}$ & $\mathrm{Y}$ & $\mathrm{Y}$ & $\mathrm{Y}$ & $\mathrm{Y}$ & $\mathrm{Y}$ & $\mathrm{Y}$ & Good Quality \\
\hline${ }^{3}$ Wang et al., 2021 & $\mathrm{Y}$ & $\mathrm{Y}$ & $\mathrm{Y}$ & $\mathrm{Y}$ & $\mathrm{Y}$ & $\mathrm{Y}$ & $\mathrm{Y}$ & $\mathrm{Y}$ & $\mathrm{Y}$ & $\mathrm{Y}$ & $\mathrm{Y}$ & $\mathrm{Y}$ & $\mathrm{Y}$ & $\mathrm{Y}$ & Good Quality \\
\hline${ }^{4}$ Wang et al., 2021 & $\mathrm{Y}$ & $\mathrm{Y}$ & $\mathrm{Y}$ & $\mathrm{Y}$ & $\mathrm{Y}$ & $\mathrm{Y}$ & $\mathrm{Y}$ & $\mathrm{Y}$ & $\mathrm{Y}$ & $\mathrm{Y}$ & $\mathrm{Y}$ & $\mathrm{Y}$ & $\mathrm{Y}$ & $\mathrm{Y}$ & Good Quality \\
\hline
\end{tabular}

${ }^{1}$ Liu J, Li B, Chen Q, Dang J. Student Health Implications of School Closures during the COVID-19 Pandemic: New Evidence on the Association of e-Learning, Outdoor Exercise, and Myopia. Healthcare (Basel).; ${ }^{2}$ Liu J, Li B, Sun Y, Chen Q, Dang J. Adolescent Vision Health During the Outbreak of COVID-19: Association Between Digital Screen Use and Myopia Progression. Front Pediatr; ${ }^{3}$ Wang, J, Li, Y, Musch, DC, et al. Progression of myopia in school-aged children after COVID-19 home confinement; ${ }^{4}$ Wang W, Zhu L, Zheng S, Ji Y, Xiang Y, Lv B, Xiong L, Li Z, Yi S, Huang H, Zhang L, Liu F, Wan W, Hu K. Survey on the Progression of Myopia in Children and Adolescents in Chongqing During COVID-19 Pandemic. 


\subsection{Characteristics of include studies}

Table 3 Studies included in our systematic review regarding the impact of digital screen use of myopia progression in the COVID-19 pandemic

\begin{tabular}{|c|c|c|c|c|c|c|c|c|c|}
\hline Reference & Country & Title & $\begin{array}{l}\text { Participa } \\
\text { nts }\end{array}$ & $\begin{array}{l}\text { Age/ } \\
\text { Grade }\end{array}$ & $\begin{array}{l}\text { Study } \\
\text { type }\end{array}$ & $\begin{array}{l}\text { Participant } \\
\text { condition at } \\
\text { baseline }\end{array}$ & $\begin{array}{l}\text { Screen } \\
\text { texposure }\end{array}$ & $\begin{array}{l}\text { Refractive } \\
\text { measuremen } \\
\text { t }\end{array}$ & Result \\
\hline $\begin{array}{l}\text { Aslan et al. } \\
2021\end{array}$ & ,Turkey & $\begin{array}{l}\text { The effect of } \\
\text { home } \\
\text { on } \\
\text { progression myopia in } \\
\text { children during } \\
\text { the } \quad \text { COVID-19 } \\
\text { pandemic }\end{array}$ & 115 & $\mid \begin{array}{lll}8 & - & 17 \\
\text { years } & \end{array}$ & Cohort & $\begin{array}{l}\text { Subjects with } \\
\text { myopia }\end{array}$ & $\begin{array}{l}\text { Computer, } \\
\text { television, } \\
\text { tablet, } \\
\text { smartphone }\end{array}$ & $\begin{array}{l}\text { Auto Kerato- } \\
\text { refractometer } \\
\text { (Nidek ARK1- } \\
\text { S, Nidek, San } \\
\text { Jose, CA, USA) }\end{array}$ & $\begin{array}{l}\text { The mean SE of the refractive values was } \\
-1.14 \pm 0.66 \mathrm{D} \text { in } 2016,-1.47 \pm 0.82 \mathrm{D} \text { in } \\
2017,-0.45 \pm 0.91 \mathrm{D} \text { in } 2018,-1.99 \pm 1.04 \mathrm{D} \\
\text { in } 2019 \text { and }-2.7 \pm 1.21 \mathrm{D} \text { in } 2020 \text {. Annual } \\
\text { progression analysis revealed a myopic } \\
\text { progression of } 0.71 \pm 0.46 \mathrm{D} \text { in } 2020 \text { and } \\
\text { this value was significantly higher than in } \\
2019 \text { and } 2018(0.54 \pm 0.43, \mathrm{p}=0.003 \text {; and } \\
0.41 \pm 0.36, \mathrm{p}<0.001, \text { respectively). }\end{array}$ \\
\hline $\begin{array}{l}\text { Liu et al. } \\
2021\end{array}$ & China & $\begin{array}{lr}\text { Student Health } \\
\text { Implications of } \\
\text { School Closures } \\
\text { during r the } \\
\text { COVID-19 } \\
\text { Pandemic: New } \\
\text { Evidence on the } \\
\text { Association of e- } \\
\text { Learning, } \\
\text { Outdoor } \\
\text { Exercise, and } \\
\text { Myopia }\end{array}$ & & $\begin{array}{l}\text { Primary, } \\
\text { lower- } \\
\text { secondary, } \\
\text { upper- } \\
\text { secondary }\end{array}$ & $\begin{array}{l}\text { Cross- } \\
\text { sectional }\end{array}$ & $\begin{array}{l}\text { Subjects with } \\
\text { and withou } \\
\text { myopia }\end{array}$ & $\begin{array}{l}\text { h } \\
\text { television, } \\
\text { computer, } \\
\text { smartphone }\end{array}$ & $\begin{array}{l}\text { Questionnaire } \\
\text { | }\end{array}$ & $\begin{array}{l}1374(40.4 \%) \text { reported suffering from } \\
\text { myopia prior to the COVID-19 pandemic. } \\
\text { Subjects who suffer from a pre-pandemic } \\
\text { myopia condition are also more likely to } \\
\text { report symptomatic myopia progression } \\
\text { during the COVID-19 pandemic }(\chi 2= \\
338.785, \mathrm{p}<0.001)\end{array}$ \\
\hline
\end{tabular}




\begin{tabular}{|c|c|c|c|c|c|c|c|c|}
\hline $\begin{array}{l}\text { Liu et } \\
2021\end{array}$ & al., China & $\mid \begin{array}{lr}\text { Adolescent } \\
\text { Vision } \\
\text { During } & \text { Health } \\
\text { Outbreak } & \text { of } \\
\text { COVID-19: } \\
\text { Association } \\
\text { Between Digital } \\
\text { Screen Use and } \\
\text { Myopia } \\
\text { Progression }\end{array}$ & 3831 & \begin{tabular}{|l|} 
Pre- \\
primary, \\
primary, \\
lower- \\
secondary, \\
upper- \\
secondary
\end{tabular} & $\begin{array}{l}\text { Cross- } \\
\text { sectional }\end{array}$ & \begin{tabular}{|l|l|} 
Subjects with & Television, \\
and without & computer, \\
myopia & smartphone
\end{tabular} & Questionnaire & $\begin{array}{l}\text { As for prevalence of myopic condition prior } \\
\text { to the COVID- } 19 \text { pandemic, } 2,440(63.7 \%) \\
\text { respondents report no issues, whereas } \\
1,291(36.3 \%) \text { report existing myopic } \\
\text { condition. Respondents who are already } \\
\text { myopic prior to the COVID- } 19 \text { pandemic } \\
\text { tend to report myopic progression at higher } \\
\text { rates (p < 0.001) than those who did not } \\
\text { self-identify as suffering from myopia in } \\
\text { pre-pandemic times. Results also indicate } \\
\text { that pre-COVID myopia condition (OR = } \\
2.74,95 \% \text { CI: } 2.32-3.23) \text { is associated with } \\
\text { higher risks of myopic progression. }\end{array}$ \\
\hline $\begin{array}{l}\text { Liu et } \\
2021\end{array}$ & al., China & $\begin{array}{lr}\text { Examining } & \text { risk } \\
\text { factors } & \text { related to } \\
\text { digital } & \text { learning } \\
\text { and } & \text { social } \\
\text { isolation: } & \text { Youth } \\
\text { visual } & \text { acuity } \\
\text { COVID-19 } \\
\text { pandemic }\end{array}$ & & $\begin{array}{l}\text { Primary, } \\
\text { secondary, } \\
\text { university }\end{array}$ & Cohort & \begin{tabular}{|l|l} 
Subjects with & Television, \\
and without & computer, \\
myopia & smartphone
\end{tabular} & Questionnaire & $\begin{array}{l}\text { Subjects who already suffer from myopia } \\
\text { prior to the COVID- } 19 \text { pandemic appear to } \\
\text { experience higher rates of symptomatic } \\
\text { myopia development during the school } \\
\text { closures }(\chi 2=381.99, P<0.001) \text {. Every one- } \\
\text { hour increase in unweighted digital device } \\
\text { use is associated with odds ratio }(\mathrm{OR})=1.25 \\
(95 \% \text { CI }=1.21-1.30 ; P<0.001) \text { increased } \\
\text { incidence of myopic symptoms. }\end{array}$ \\
\hline $\begin{array}{l}\mathrm{Ma} \\
2021\end{array}$ & al., China & $\begin{array}{l}\text { COVID-19 Home } \\
\text { Quarantine } \\
\text { Accelerated the } \\
\text { Progression of } \\
\text { Myopia } \\
\text { Children Aged } 7 \\
\text { to 12 Years in } \\
\text { China }\end{array}$ & 201 & $\left|\begin{array}{lll}7 & - & 12 \\
\text { years } & \end{array}\right|$ & Cohort & \begin{tabular}{|l|l}
$\begin{array}{l}\text { Subjects with } \\
\text { myopia }\end{array}$ & $\begin{array}{l}\text { Smartphone, } \\
\text { tablet, } \\
\text { television, } \\
\text { projector }\end{array}$
\end{tabular} & $\begin{array}{l}\text { Autorefractor } \\
\text { (KR-8900; } \\
\text { Topcon, } \\
\text { Tokyo, Japan) } \\
\end{array}$ & $\begin{array}{l}\text { During the first half-year period, greater } \\
\text { myopia progression was associated with } \\
\text { less outdoor time }(\mathrm{r}=0.401, \mathrm{P}<0.001) \text {, } \\
\text { more near work }(\mathrm{r}=-0.394, \mathrm{P}<0.001) \text {, and } \\
\text { more digital screen time for online learning } \\
(\mathrm{r}=-0.244, \mathrm{P}<0.001) \text {. During the second } \\
\text { half-year period, greater myopia } \\
\text { progression was significantly correlated to } \\
\text { more digital screen time for online learning } \\
(\mathrm{r}=-0.360, \mathrm{P}<0.001) \text {. The increase in } \\
\text { myopia from visit } 1 \text { to visit } 2(-0.98 \pm 0.52 \\
\mathrm{D}, 5.4 \text { months }) \text { was nearly three times } \\
\text { greater than that from baseline to visit } 1 \\
(-0.39 \pm 0.58 \mathrm{D}, 5.7 \text { months). }\end{array}$ \\
\hline
\end{tabular}




\begin{tabular}{|c|c|c|c|c|c|c|c|}
\hline $\begin{array}{l}\text { Ma et al., } \\
2021\end{array}$ & ., China & $\mid \begin{array}{l}\text { Progression of } \\
\text { myopia in a } \\
\text { natural cohort of } \\
\text { Chinese children } \\
\text { during COVID-19 } \\
\text { pandemic }\end{array}$ & $\mid \begin{array}{lll}8 & - & 10 \\
\text { years } & \end{array}$ & Cohort & $\begin{array}{l}\text { Subjects with } \\
\text { and without } \\
\text { and lomputer, } \\
\text { myopia }\end{array}$ & $\begin{array}{l}\text { Autorefractor- } \\
\text { keratometry } \\
\text { (KR8800, } \\
\text { Topcon, } \\
\text { Tokyo, Japan) }\end{array}$ & $\begin{array}{l}7 \text { months before the COVID-19, the mean } \\
\text { myopia progression was }-0.3 \mathrm{D} \text { and this } \\
\text { difference was found to be statistically } \\
\text { significant. The myopia progression } \\
\text { was-0.9D in } 7 \text { months during studying at } \\
\text { home. }\end{array}$ \\
\hline $\begin{array}{l}\text { Wang et al., } \\
2021\end{array}$ & .. China & $\mid \begin{array}{ll}\text { Progression of } & 123535 \\
\text { Myopia in } & \text { in } \\
\text { School-Aged } \\
\text { Children After } \\
\text { COVID-19 Home } \\
\text { Confinement }\end{array}$ & $\left|\begin{array}{ll}6-13 & \\
\text { years } \\
\text { Grade } & 1- \\
6) & \end{array}\right|$ & $\begin{array}{l}\text { Cross- } \\
\text { sectional }\end{array}$ & $\mid \begin{array}{l}\text { Subjects with } \\
\text { and wot } \\
\text { myopia }\end{array}$ & $\begin{array}{l}\text { Spot Vision } \\
\text { Screener, } \\
\text { version 2.1.4 } \\
\text { (Welch Allyn) } \\
\qquad \\
\\
\\
\end{array}$ & $\begin{array}{l}\text { The prevalence of myopia in this age group } \\
\text { in } 2020 \text { was } 21.5 \% \text { at } 6 \text { years, } 26.2 \% \text { at } 7 \\
4 \text { years, and } 37.2 \% \text { at } 8 \text { years. These levels } \\
\text { were significantly higher than the highest } \\
\text { prevalence of myopia in } 2015-2019 \text { for } \\
\text { these age groups: } 5.7 \% \text { at } 6 \text { years in } 2019, \\
16.2 \% \text { at } 7 \text { years in } 2018 \text {, and } 27.7 \% \text { at } 8 \\
\text { years in } 2018 \text {. Although the prevalence of } \\
\text { myopia for children aged } 9 \text { years ( } 45.3 \% \text { ) in } \\
2020 \text { was the highest prevalence across the } \\
6 \text { years of measurement, it was not } \\
\text { substantially different from the second } \\
\text { highest prevalence in } 2018 \text { (43.5\%). The } \\
\text { prevalence of myopia in } 2020 \text { ceased to be } \\
\text { the highest among the } 6 \text { years for children } \\
\text { aged } 10 \text { to } 13 \text { years } \\
\text { Such a substantial increase in the } \\
\text { prevalence of myopia was not seen in the } \\
\text { older age groups ( } 9-13 \text { years). }\end{array}$ \\
\hline $\begin{array}{l}\text { Wang et al., } \\
2021\end{array}$ & ., China & 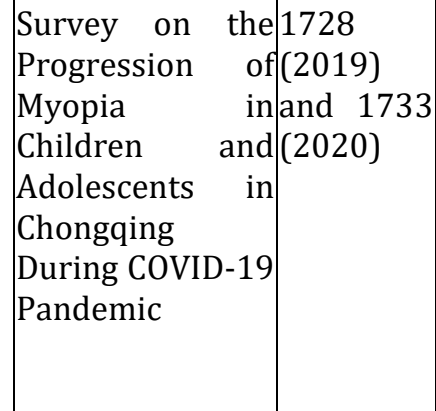 & $\left|\begin{array}{lr}\text { Grades } & 1-6 \\
\text { primary } \\
\text { school, } \\
\text { grades } \quad 1 \\
\text { and 2 in } \\
\text { junior } \\
\text { school, and } \\
\text { grades } 1 \\
\text { and } 2 \text { in } \\
\text { high school }\end{array}\right|$ & 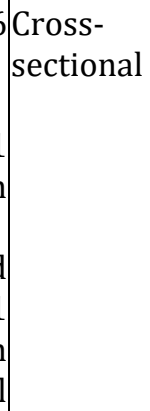 & \begin{tabular}{|l|l} 
Subjects with & Smartphone, \\
and without & tablet, \\
myopia & $\begin{array}{l}\text { computer, } \\
\text { television, } \\
\text { projector }\end{array}$
\end{tabular} & $\begin{array}{l}\text { Optometry } \\
\text { unit (Supore, } \\
\text { China) }\end{array}$ & $\begin{array}{l}\text { The overall percentage of myopia among } \\
\text { teenagers in } 2020 \text { was } 55.02 \% \text {, which was } \\
\text { increased by } 10.40 \% \text { as compared to that in } \\
2019(44.62 \%) \text {. In } 2020 \text {, the percentages of } \\
\text { myopia were } 84.89 \% \text { in high school, } \\
73.39 \% \text { in junior school, and } 39.27 \% \text { in } \\
\text { primary school, which were significantly } \\
\text { higher than those in } 2019 \text {. }\end{array}$ \\
\hline
\end{tabular}




\begin{tabular}{|c|c|c|c|c|c|c|c|c|}
\hline $\begin{array}{l}\text { Zhang et al., } \\
2021\end{array}$ & 1., Hong Kong & $\mid \begin{array}{lr}\text { Myopia incidence } & 709 \\
\text { and r lifestyle } \\
\text { changes among } \\
\text { school children } \\
\text { during r the } \\
\text { COVID-19 } \\
\text { pandemic: a } \\
\text { population- } \\
\text { based } \\
\text { prospective } \\
\text { study }\end{array}$ & $\mid \begin{array}{l}6-8 \text { years } \\
\text { (Primary } \\
\text { school) }\end{array}$ & Cohort & $\begin{array}{l}\text { Subjects } \\
\text { without } \\
\text { myopia }\end{array}$ & $\begin{array}{l}\text { Television, } \\
\text { computer, } \\
\text { smartphone, } \\
\text { tablet }\end{array}$ & $\begin{array}{l}\text { Autorefractor } \\
\text { (ARK-510A, } \\
\text { Nidek, } \\
\text { Gamagori, } \\
\text { Japan) }\end{array}$ & $\begin{array}{l}\text { Myopia incidence of } 19.44 \% \text { over } 8 \text {-months' } \\
\text { follow-up in COVID- } 19 \text {. In the COVID-19 } \\
\text { cohort, myopia incidence was } 19.44 \% \\
(112 / 576) \text { in total, } 18.05 \%(37 / 205), \\
22.16 \%(43 / 194) \text { and } 18.08 \%(32 / 177) \text { in } \\
6,7-\text { and 8-year old groups (p=0.58) over } 8 \\
\text { months, respectively. In the pre-COVID-19 } \\
\text { cohort, myopia incidence was } 36.57 \% \\
(324 / 886) \text { in total, } 41.54 \%(108 / 260), \\
34.47 \%(101 / 293) \text { and } 34.53 \%(115 / 333) \\
\text { in 6, 7- and 8-year old groups (p=0.90) after } \\
3 \text { years, respectively. }\end{array}$ \\
\hline $\begin{array}{l}\text { Mohan et al., } \\
2022\end{array}$ & l., India & $\begin{array}{l}\text { Impact of online } \\
\text { classes and home } \\
\text { confinement on } \\
\text { myopia } \\
\text { progression in } \\
\text { children during } \\
\text { COVID-19 } \\
\text { pandemic: Digital } \\
\text { eye strain among } \\
\text { kids } \\
\text { study } 4\end{array}$ & $\begin{array}{lll}6 & - & 18 \\
\text { years } & \end{array}$ & Cohort & $\begin{array}{l}\text { Subjects with } \\
\text { myopia }\end{array}$ & Smartphone & $\begin{array}{l}\text { Topcon auto } \\
\text { refractor } \\
\text { KR8900 } \\
\text { (Topcon, } \\
\text { Tokyo, Japan), } \\
\text { Heine beta } \\
200 \\
\text { retinoscope } \\
\text { (Heine } \\
\text { Optotechnik, } \\
\text { Herrsching, } \\
\text { Germany) }\end{array}$ & $\begin{array}{l}\text { Myopia progression before and during the } \\
\text { COVID-19 pandemic, } 62.4 \% \text { of the children } \\
\text { showed progression during the pandemic } \\
\text { as compared with } 45.9 \% \text { before the } \\
\text { pandemic (P }=0.006 \text { ). Mean annual myopia } \\
\text { progression was found to be statistically } \\
\text { significant during COVID- } 19 \text { as compared } \\
\text { with pre-COVID-19 period }(0.90 \text { vs } 0.25 \mathrm{D}, \mathrm{P} \\
<0.00001) \text {. A total of } 45.9 \% \text { of children } \\
\text { showed an annual progression of } \geq 1 \mathrm{D} \\
\text { during the pandemic as compared with } \\
10.5 \% \text { before the COVID- } 19 \text { pandemic }(\mathrm{P}< \\
0.00001) \text {. }\end{array}$ \\
\hline
\end{tabular}


The studies analyzed were published between 2020 and 2022 (Table 3). The majority of the studies (70\%) were conducted in China [8,13,14,15,16,17,18], with others coming from Hong Kong [7], India [19], and Turkey [20]. Four $(40 \%)$ of the ten studies were cross-sectional [8,13,14,18], while the other six $(60 \%)$ were cohort studies $[7,15,16,17,19,20]$. The sample size ranged from 115 to 123535 participants. The majority of the participants in the studies were school-age children (primary and secondary school), but one study included university students [15]. There were three studies involving subjects with myopia at baseline $[16,19,20]$, one study involving subjects without myopia at baseline [20], and six studies involving subjects with myopia and without myopia $[8,13,14,15,17,18]$.

Questionnaires were used in studies to determine what type of digital device exposed the subject. The use of digital screens in the studies obtained varied; computers, tablets, smartphones, televisions, and projectors. One study did not specify the type of digital device used to expose the subjects [8]. To investigate the visual status, each subject was required to take a refractive measurement in order to determine the mean spherical equivalent (SE) refraction or refractive error. Refraction was measured in seven (70\%) of the ten studies [7,8,16,17,18,19,20]. Vision screening [8], autorefractor [7,16,17,19,20], retinoscope [19], and optometry [18] are the refractive measures used. The remaining three studies use self-reported myopia, which uses a questionnaire as a self-evaluation of respondents regarding symptomatic changes in their vision condition using terminology that subjects are familiar with, rather than a standardized ophthalmological examination $[13,14,15]$.

The prevalence or incidence of myopia was reported in all ten studies. According to one study [8], the prevalence of myopia in the age group 6-8 years in 2020 (21.5 percent at 6 years, 26.2 percent at 7 years, and 37.2 percent at 8 years) was significantly higher than the highest prevalence of myopia in 2015-2019 (5.7 percent at 6 years in $2019,16.2$ percent at 7 years in 2018, and 27.7 percent at 8 years in 2018), whereas such a significant increase in myopia prevalence was not seen in the older age groups (9-13 years).

The overall number of myopia among teenagers in 2020 was 55.02 percent, up 10.40 percent from the previous year (44.62 percent) [18]. A study [7], which included participants who did not have myopia at the baseline, was one of the first to report myopia progression during this pandemic, with a myopia incidence of 19.44 percent in COVID-19 after an 8-month follow-up. The incidence of myopia in this study was defined as myopia detected during the follow-up ophthalmic examination among subjects who did not have myopia at baseline [7].

Myopia progression was reported in studies with myopic children before and during the COVID-19 pandemic, with 62.4 percent of the children showing progression during the pandemic compared to 45.9 percent before the pandemic $(\mathrm{P}=$ 0.006). During the pandemic, 45.9 percent of children showed an annual progression of $1 \mathrm{D}$, compared to 10.5 percent before the COVID-19 pandemic (P 0.00001) [19].

Studies with subjects of myopic children reported myopia progression before and during the COVID-19 pandemic, $62.4 \%$ of the children showed progression during the pandemic as compared with $45.9 \%$ before the pandemic $(\mathrm{P}=$ 0.006 ) A total of $45.9 \%$ of children showed an annual progression of $1 \mathrm{D}$ during the pandemic as compared with $10.5 \%$ before the COVID-19 pandemic ( $<<0.00001)$ [19]. Studies also found that subjects with pre-pandemic myopia are more likely to report symptomatic myopia progression during the COVID-19 pandemic than those who did not self-identify as having myopia prior to the pandemic. Subjects who already had myopia prior to the COVID-19 pandemic appear to have a higher rate of symptomatic myopia development during school closures $[13,14,15]$. It is stated that higher myopia progression was significantly correlated with more digital screen time for online learning during the second half-year period [16].

Findings showed that myopia progression was -0.9D in 7 months while studying at home, which was found to be statistically significant when compared to the mean myopia progression was $-0.3 \mathrm{D}$ in 7 months prior to the COVID-19 [17]. Another research revealed that annual analysis revealed a myopic progression of $0.71 \pm 0.46 \mathrm{D}$ in 2020 , which was significantly higher than the values found in 2019 and 2018 [20].

\section{Discussion}

This systematic review provides some studies that indicate that the use of digital screens may be correlated with myopia progression. This study was determined through a systematic review of cross-sectional and cohort studies. In our study, myopia progression was defined as myopia detected during the follow-up ophthalmic examination in subjects who did not have myopia at baseline or myopia detected increased during the follow-up ophthalmic examination in subjects who already had myopia at baseline. However, there are some studies that do not objectively measure myopia with a standardized ophthalmological examination. In addition, the duration of digital screen use associated with myopia progression was not included in our study. 
Following the World Health Organization's (WHO) designation of COVID-19 as a global pandemic on March 11, 2020, widespread changes and restrictions to social and sanitary practices have raised significant concerns [2]. For example, school-aged children were restricted to their homes for several months while online classes were offered. Their daily online course hours are one hour for grades one and two, and 2.5 hours for grades three through six. As a result, children's indoor activities and screen time increased, while their outdoor activities decreased, often to zero [8]. Although school closures due to the pandemic will not last indefinitely, the increasing adoption and reliance on digital screens may have long-term effects on myopia progression in the population, particularly among children. This is a concern discussed by the international ophthalmic community [6].

Looking at the issue of increased usage of digital screens as a consequence of the COVID-19 pandemic, multiple studies discovered a follow-up influence from this incident. They have already shown the unnoticed consequence of increased digital screen usage, which has been correlated and influenced to the onset and progression of myopia, which might possibly increase during and after the COVID-19 pandemic [8,12,21]. Due to rapidly rising screen time use at home, the longer duration of lockdown during the COVID-19 pandemic may have exacerbated the burden of myopia [5,22,23]. It might be possible because increased digital screen usage is one of the major risk factors for myopia [24,25].

The prevalence of myopia reported to be approximately 1.4 to 3 times higher in 2020 than in other years for children aged 6-8 years whereas in the older age category did not show an increase as high as in younger children, these findings lead us to conclude that younger children are more susceptible to environmental change than older children [8]. Not only in children but there is also evidence that the pandemic has hastened the progression of myopia in both (children and adolescents) [18].

Latest researches have also discovered that myopic children spend more time playing computer and video games compared to nonmyopic children, and that excessive use of screen devices was associated with increasing myopia prevalence, particularly when using devices for more than 3 hours per day [11,26]. Another study, done in Denmark with a research sample of teenagers, also discovered that digital screen usage accounted for roughly $25 \%$ of the reported prevalence of myopia, with the risk of myopia worsening if digital screen use exceeded 6 hours per day [11]. Several research findings support all of those claims, stating that each additional diopter hour of digital screen use is related to the increased likelihood of symptomatic myopia development, which can be translated as significant risks given the extended periods of time young children spend in front of screens [13]. So, it showed that the intensity of digital screen time use is related to an increased chance of acquiring symptomatic myopia [14].

Based on all of the studies that mention a relationship between digital screen use and the progression of myopia, all of these statements make sense with the explanation of a study conducted on mice, where they explained that blue light emitted from computer screens, for example, has dangerous effects on the retinal pigment epithelium so that it can lead to retinal pigment epithelial dysfunction, that might result in axial elongation and the progression of pathological myopia [27]. It can even cause the outer blood-retinal barrier among the neuroretina and the choroid to become destabilized, resulting in crucial delays in retinal development signals [28,29]. Indeed, it has been established that using near vision eyes causes the ciliary muscle to tighten, the refractive power of the retina will rise, the axis of the eye to lengthen, and myopic vision diseases may occur [30,31]. Additionally, this is in line with the public's situation during the epidemic, due to online instructional and learning requirements, a sharp increase in digital device engagement may expose people to excessive near-view hyperopic defocus stimulation, while persistent peripheral hyperopic defocus causes compensatory abnormal expansion of axial myopic eyes and lead to the development of premature refractive error $[32,33,34]$.

Environmental factors do have a tremendous impact on the progression of myopia. These factors include exposure to light, lack of physical activity, and level of education [35]. Of these factors, less light exposure makes it difficult for the eye to focus properly or the increased pupil size during dark conditions allows more unfocused peripheral light rays to enter the eye, thus increasing the risk of myopia. This is also supported by research which states that less outdoor time and less light exposure are correlated with increased myopia prevalence and, in some reports, also with myopia progression [36]. This means that if a person already suffers from myopia and is accompanied by the use of less light, it can cause the progression of myopia to increase.

Myopia represents a significant socioeconomic burden globally and, if left uncorrected, can affect school performance of children and quality of life [3]. Pathological myopia occurs when high myopia causes a decline in best corrected visual acuity as a result of associated consequences. One of the most common causes of blindness is pathological myopia. Myopia is a major cause of visual disability among children, and also predisposes them to multiple ocular complications that increase the risk of irreversible vision loss later in life [37]. 
Complications that can be caused by myopia are very dangerous, so we must take precautions in order for myopia progression to not get worse. Prevention efforts can include spending more time outside. Spending more time outside than indoors protects against the development of myopia [38]. Adequate lighting in the room is also able to reduce the risk of myopia. Even slight gains in classroom lighting have been shown to significantly reduce the onset of myopia in one intervention trial [39]. If you have to stare at a screen all day to work, it's better to stick to the 20-20-20 rule. This means that after 20 minutes of screen time, you must try to stare at anything 20 feet away for a total of 20 seconds. The 20-20-20 rule results in significant improvements in dry eye symptoms and tear film, as well as some minor improvements in ocular surface integrity [40]. During the COVID-19 pandemic, people tend not to visit doctors for eye health consultations. In fact, children and adolescents should undergo regular comprehensive eye health examinations, especially those related to refractive status [41]. So to prevent the occurrence of myopia and the progression of myopia, regular check-ups by a doctor regarding eye health need to be carried out.

Certain limitations in our study should be acknowledged. First, there is one study in this review that is supported by the Fund Sponsorship of the Capital Public Health Project, the Beijing Natural Science Foundation, the Capital health research and development of special, and the National Natural Science Foundation of China. Second, several reviewed studies rely on self-reported myopia as measured by a questionnaire rather than a standardized ophthalmological examination. While standardized ophthalmic evaluations would be ideal for obtaining detailed objective information on refractive error, previous research has shown that subjects' self-assessment of vision status does not differ systematically from professional ophthalmic evaluation. Questionnaire survey designs have also become increasingly common in optometry because of their low cost-effectiveness. However, future studies may find that professional ophthalmic evaluations are more useful than subject self-reports. Finally, our review did not include the duration of the digital screen used during the pandemic, as well as the distance between the eyes and the screen. Further research is needed to determine the impact of these factors on myopia progression.

\section{Conclusion}

In conclusion, this systematic review shows that there is a significant progression of myopia as an impact of digital screen use during the COVID-19 pandemic. It is well understood that uncorrected myopia can negatively impact children's school performance and quality of life. Since myopia is also a major cause of blindness and can predispose to other ocular complications, it is critical to take precautionary measures to ensure that myopia does not worsen, causing irreversible vision loss later in life. To reduce the risk of developing myopia, we recommend spending more time outside, having adequate lighting in the room, and limiting your use of digital screens. If you must stare at a screen all day for work, follow the 20-20-20 rule. Lastly, it is essential to have regular comprehensive eye health examinations.

\section{Compliance with ethical standards}

\section{Acknowledgments}

All authors equally contributed and acknowledge to read and approved the study.

\section{Disclosure of conflict of interest}

No conflict of interest is reported.

\section{References}

[1] Qiao C, Zhang H, He M, Ying G, Chen C, Song Y, Oatts J, Liu Z, Xing Y, Xiao Z, Ke M, Ye Y, Chen X, Luo J, Han Y, Wang N. Symptomatic COVID19 in eye professionals in Wuhan China. Ophthalmology. 2020; 127(9): 1268-1270.

[2] World Health Organization [Internet]. Coronavirus disease 2019 (COVID-19) situation report - 145. Geneva: World Health Organization. 2020.

[3] Foster PJ, Jiang Y. Epidemiology of myopia. Eye (London, England). 2014; 28(2): 202-208.

[4] Holden BA, Fricke TR, Wilson DA, Jong M, Naidoo KS, Sankaridurg P, Wong TY, Naduvilath TJ, Resnikoff S. Global prevalence of myopia and high myopia and temporal trends from 2000 through 2050. Ophthalmology. 2016; 123(5): 1036-42.

[5] Sumitha M, Sanjay S, Kemmanu V, Bhanumathi MR, Shetty R. Will COVID-19 pandemic-associated lockdown increase myopia in Indian children. Indian Journal of Ophthalmology. 2020 Jul; 68(7): 1496. 
[6] Wong CW, Tsai A, Jonas JB, Ohno-Matsui K, Chen J, Ang M, Ting DSW. Digital screen time during the covid-19 pandemic: Risk for a further myopia boom?. American Journal of Ophthalmology. 2021; 223: 333-7.

[7] Zhang X, Cheung SSL, Chan HN, Zhang Y, Wang YM, Yip BH, Kam KW, Yu M, Cheng CY, Young AL, Kwan MYW, Ip P, Chong KK, Tham CC, Chen LJ, Pang CP, Yam JCS. Myopia incidence and lifestyle changes among school children during the COVID-19 pandemic: a population-based prospective study. British Journal of Ophthalmology. 2021.

[8] Wang J, Li Y, Musch DC, Wei N, Qi X, Ding G, Li X, Li J, Song L, Zhang Y, Ning Y, Zeng X, Hua N, Li S, Qian X. Progression of myopia in school-aged children after COVID-19 home confinement. JAMA Ophthalmology. 2021; 139(3): 293-300.

[9] Saw SM, Matsumura S, Hoang QV. Prevention and Management of Myopia and Myopic Pathology. Investigative Ophthalmology \& Visual Science. 2019; 60(2): 488-499.

[10] Liang YB, Lin Z, Vasudevan B, Jhanji V, Young A, Gao TY, Rong SS, Wang NL, Ciuffreda KJ. Generational difference of refractive error in the baseline study of the Beijing Myopia Progression Study. British Journal of Ophthalmology. 2013; 97(6): 765.

[11] Hansen MH, Laigaard PP, Olsen EM, Skovgaard AM, Larsen M, Kessel L, Munch IC. Low physical activity and higher use of screen devices are associated with myopia at the age of 16-17 years in the CCC2000 eye study. Acta Ophthalmologica. 2019; 98(3): 315-21.

[12] Shu DWT, Carin L, Dzau V, Wong TY. Digital technology and COVID-19. Nature Medicine. 2020; 26 (4): $459-61$.

[13] Liu J, Li B, Chen Q, Dang J. Student Health Implications of School Closures during the COVID-19 Pandemic: New Evidence on the Association of e-Learning, Outdoor Exercise, and Myopia. Healthcare (Basel). 23 Apr 2021; 9(5): 500 .

[14] Liu J, Li B, Sun Y, Chen Q, Dang J. Adolescent Vision Health During the Outbreak of COVID-19: Association Between Digital Screen Use and Myopia Progression. Frontiers in Pediatrics. 25 May 2021; 9: 662984.

[15] Liu J, Chen Q, Dang J. Examining risk factors related to digital learning and social isolation: Youth visual acuity in COVID-19 pandemic. Journal of Global Health. 21 Aug 2021; 11: 05020.

[16] Ma M, Xiong S, Zhao S, Zheng Z, Sun T, Li C. COVID-19 Home Quarantine Accelerated the Progression of Myopia in Children Aged 7 to 12 Years in China. Investigative Ophthalmology \& Visual Science. 2 Aug 2021; 62(10): 37.

[17] Ma D, Wei S, Li SM, Yang X, Cao K, Hu J, Fan S, Zhang L, Wang N. Progression of myopia in a natural cohort of Chinese children during COVID-19 pandemic. Graefe's Archive for Clinical and Experimental Ophthalmology. Sep 2021; 259(9): 2813-2820.

[18] Wang W, Zhu L, Zheng S, Ji Y, Xiang Y, Lv B, Xiong L, Li Z, Yi S, Huang H, Zhang L, Liu F, Wan W, Hu K. Survey on the Progression of Myopia in Children and Adolescents in Chongqing During COVID-19 Pandemic. Frontiers in Public Health. 28 Apr 2021; 9: 646770.

[19] Mohan A, Sen P, Peeush P, Shah C, Jain E. Impact of online classes and home confinement on myopia progression in children during COVID-19 pandemic: Digital eye strain among kids (DESK) study 4. Indian Journal of Ophthalmology. Jan 2022; 70(1): 241-245.

[20] Aslan F, Sahinoglu-Keskek N. The effect of home education on myopia progression in children during the COVID19 pandemic. Eye (London, England). 30 Jun 2021: 1-6.

[21] Yang GY, Huang LH, Schmid KL, Li CG, Chen JY, He GH, Liu L, Ruan ZL, Chen WQ. Associations between Screen Exposure in Early Life and Myopia amongst Chinese Preschoolers. International Journal of Environmental Research and Public Health. 2020; 17(3): 1056.

[22] Pellegrini M, Bernabei F, Scorcia V, Giannaccare G. May home confinement during the COVID-19 outbreak worsen the global burden of myopia?. Graefe's Archive for Clinical and Experimental Ophthalmology. 2020; 258(9): 2069-2070.

[23] Navel V, Beze S, Dutheil F. COVID-19, sweat, tears... and myopia?. Clinical and Experimental Optometry. 2020; 103(4): 555 .

[24] Rose KA, French AN, Morgan IG. Environmental factors and myopia: paradoxes and prospects for prevention. The Asia-Pacific Journal of Ophthalmology. 2016; 5(6): 403-10. 
[25] Saxena R, Vashist P, Tandon R, Pandey RM, Bhardawaj A, Gupta V, Menon V. Incidence and progression of myopia and associated factors in urban school children in Delhi: The North India Myopia Study (NIM Study). PLoS One. 2017; 12: e0189774.

[26] Harrington SC, Stack J, O’Dwyer V. Risk factors associated with myopia in schoolchildren in Ireland. British Journal of Ophthalmology. 2019; 103(12): 1803-1809.

[27] Narimatsu T, Negishi K, Miyake S, Hirasawa M, Osada H, Kurihara T, Tsubota K, Ozawa Y. Blue light-induced inflammatory marker expression in the retinal pigment epithelium-choroid of mice and the protective effect of a yellow intraocular lens material in vivo. Experimental Eye Research. 2015; 132: 48-51.

[28] Strauss 0. The retinal pigment epithelium in visual function. Physiological Reviews. 2005; 85: 845-81.

[29] Rymer J, Wildsoet CF. The role of the retinal pigment epithelium in eye growth regulation and myopia: a review. Visual Neuroscience. 2005; 22(3): 251-61.

[30] Bailey MD, Sinnott LT, Mutti DO. Ciliary body thickness and refractive error in children. Investigative Ophthalmology \& Visual Science. 2008; 49(10): 4353-60.

[31] McBrien N, Gentle A. Role of the sclera in the development and pathological complications of myopia. Progress in Retinal and Eye Research. 2003; 22: 307- 38.

[32] Saw SM, Gazzard G, Shih-Yen EC, Chua WH. Myopia and Associated Pathological Complications. Ophthalmic and Physiological Optics. 2005; 25(5): 381-91.

[33] Long J, Cheung R, Duong S, Paynter R, Asper L. Viewing distance and eyestrain symptoms with prolonged viewing of smartphones. Clinical and Experimental Optometry. 2017; 100(2): 133-7.

[34] Smith EL, Hung LF, Huang J. Relative peripheral hyperopic defocus alters central refractive development in infant monkeys. Vision Research. 2009; 49(19): 2386-92.

[35] Coviltir V, Burcel M, Cherecheanu AP, Ionescu C, Dascalescu D, Potop V, Burcea M. Update on Myopia Risk Factors and Microenvironmental Changes. Journal of ophthalmology. 31 Oct 2019; 4960852.

[36] Read SA, Collins MJ, Vincent SJ. Light Exposure and Eye Growth in Childhood. Investigative Ophthalmology \& Visual Science. 2015; 56(11): 6779-6787.

[37] Haarman AE, Enthoven CA, Tideman JWL, Tedja MS, Verhoeven VJ, Klaver CC. The Complications of Myopia: A Review and Meta-Analysis. Investigative Ophthalmology \& Visual Science. 2020; 61(4): 49.

[38] Lingham, G, Mackey DA, Lucas R, Yazar S. How does spending time outdoors protect against myopia? A review. The British journal of ophthalmology. 2020; 104(5): 593-599.

[39] Hua WJ, Jin JX, Wu XY, Yang JW, Jiang X, Gao GP, Tao FB. Elevated light levels in schools have a protective effect on myopia. Ophthalmic \& physiological optics: the journal of the British College of Ophthalmic Opticians (Optometrists). 2015; 35(3): 252-262.

[40] Alghamdi WM, Alrasheed SH. Impact of an educational intervention using the 20/20/20 rule on Computer Vision Syndrome. African Vision and Eye Health. 2020; 79(1): 1-6.

[41] Wallace DK, Morse CL, Melia M, Sprunger DT, Repka MX, Lee KA, Christiansen SP. American Academy of Ophthalmology Preferred Practice Pattern Pediatric Ophthalmology/Strabismus Panel. Pediatric Eye Evaluations Preferred Practice Pattern®: I. Vision Screening in the Primary Care and Community Setting; II. Comprehensive Ophthalmic Examination. Ophthalmology. 2018; 125(1): P184-P227. 